\title{
Assessment of Radionuclide Transfer from Soil to Vegetables in Farms from Cameron Highlands and Penang, (Malaysia) Using Neutron Activation Analysis
}

\author{
Murtadha Sh. Aswood ${ }^{1,2}$, Mohamad S. Jaafar ${ }^{1} \&$ Sabar Bauk $^{3}$ \\ ${ }^{1}$ School of Physics, Universiti Sains Malaysia, Penang, Malaysia \\ ${ }^{2}$ Department of Physics, College of Education, University of Al-Qadisiya, Al-Qadisiya, Iraq \\ ${ }^{3}$ Physics Section, School of Distance Education, Universiti Sains Malaysia, USM, Penang, Malaysia \\ Correspondence: Murtadha Sh. Aswood, School of Physics, Universiti Sains Malaysia (USM), Q-5-6 Desa Sri \\ Permi Indah, Jalan Helang, Sungai Dua, Penang 11800, Malaysia. Email: murtadhababylon@gmail.com
}

Received: July 22, 2013 Accepted: August 16, 2013 Online Published: August 26, 2013

doi:10.5539/apr.v5n5p85 URL: http://dx.doi.org/10.5539/apr.v5n5p85

\begin{abstract}
The concentrations of natural radionuclide of ${ }^{238} \mathrm{U}$ and ${ }^{232} \mathrm{Th}$ have been measured by neutron activation analysis technique in essential vegetables and soil samples collected from farms in Cameron Highlands and Penang, Malaysia. The concentrations of natural radionuclide in Tomato, Eggplant, Lattice, Pumpkin, Cucumber, Onion, Okra, and Chilli were measured. In soil, the average concentrations of ${ }^{238} \mathrm{U}$ and ${ }^{232} \mathrm{Th}$ were $203.83 \pm 2.05 \mathrm{~Bq} / \mathrm{kg}$ and $186.17 \pm 3.35 \mathrm{~Bq} / \mathrm{kg}$, respectively in Cameron Highland. The highest concentrations of uranium and thorium were $6.25 \pm 1.58 \mathrm{~Bq} / \mathrm{kg}$ and $2.5 \pm 1.55 \mathrm{~Bq} / \mathrm{kg}$ in cucumber and lettuce products, respectively in the Cameron highlands. The transfer factors of these radionuclides from soil to vegetables were estimated. The highest estimation was in Cucumber and lettuce. These values were compared with the published data and were found to be within acceptable limits.
\end{abstract}

Keywords: NAA, transfer factor, soil, vegetable, uranium, thorium

\section{Introduction}

Natural radionuclides exist in every human environment; soil, water, air, food, and even our own bodies contain naturally occurring radioactive materials. Usually, the natural radionuclides are very low activity concentrations. The primordial radionuclides ${ }^{238} \mathrm{U}$ and ${ }^{232} \mathrm{Th}$ exist in soil, in varying concentrations. These can be attributed to the nature of the parent rock during soil genesis. Studying transfer of natural radionuclides, like ${ }^{238} \mathrm{U}$ and ${ }^{232} \mathrm{Th}$ along with their daughter products through the biosphere is important because their ubiquitous presence and persistence in the environment (UNSCEAR, 2000; Hasan et al., 2010; Pulhani et al., 2005). Soil-vegetables are recognized as one of the major pathways for the transfer of radionuclides to human beings (IAEA, 1982). Transmission of uranium and thorium along with nutrients through the absorption of minerals, and accumulate in various parts or even up to the edible parts.

Transfer factor (TF) is a useful parameter for the radiological assessment. It is defined as the steady-state concentration ratio between one physical situation and another. As a case in point is the ratio of the concentration of an element in dry vegetation to that in dry soil as follows (Wang et al., 1997). Transfer coefficient based on vegetation type, soil properties and the type of radionuclides. Transfer factor has been studied in many countries. In Pakistan, for instance, it was reported that the transfer factors of ${ }^{226} \mathrm{Ra},{ }^{232} \mathrm{Th}$ and ${ }^{40} \mathrm{~K}$ from soil to vegetables were estimated to be about 0.07, 0.16 and, 0.17, respectively (Hasan et al., 2010).

The analysis of these radionuclides in foodstuff is an important part of the environmental monitoring program. These natural radioactive sources are the largest contributor of the radiation doses received by mankind. Typical levels in foodstuff vary from a few tens of Becquerel $(\mathrm{Bq})$ to several hundred $\mathrm{Bq}$ per kilogram of food (Wang et al., 1997; Khan et al., 2001). Radionuclide is necessary to determine and estimate the activity of various radionuclides present in soil and their transfer factors are different in different food samples. This difference helps assess the radiation doses in human beings, the ultimate consumers of food.

Cameron Highlands farm supply over half of the Malaysian vegetable needs. They are situated in the state of 
Pahang, with a terrain height that varies from 1070 to 2110 meters above the sea level. It is a mountainous area where approximately $75 \%$ of it is above 1000 meters from the sea level (WWF Malaysia, 2001). Presently, Cameron Highlands represent a region where more than 5890 ha, are in use for agricultural purposes (Mahdieh et al., 2009) and for an intensive vegetable cultivation. The agricultural sector produces vegetables (47\%), tea (44\%), flowers $(7 \%)$ and fruits $(1 \%)$. The Penang state represents one of the 13 states of the Malaysian peninsular, situated at the north eastern coast. The state is bounded to the north and east by the state of Kedah, to the south by Perak, and to the west by Malacca (Almayahi et al., 2012).

The aim of this paper is to measure the uranium and thorium concentrations in soil and vegetables, which were collected from different locations, such as highland farms in Cameron and land farms in Penang. A neutron activation analysis technique is used to measure uranium and thorium concentrations. The transfer factor is then determined depending on the measurement and these results are later compared with internationally acceptable values.

\section{Materials and Methods}

\subsection{Study Area}

The soil and vegetable samples were collected from highland farms in Cameron and the land farm in Penang, as shown in Figure 1. A Cameron Highland, which has a total area of 71,218 ha which constitute three mukims i.e. Mukim Ulu Telom, Mukim Ringlet and Mukim Tanah Rata. Cameron Highlands shares its boundary with the states of Kelantan in the north and Perak in the west (Kumaran et al., 2004). Cameron Highlands is a popular tourist and recreational area in addition to its being a key agricultural area for vegetables, flowers, and tea (Muhammad et al., 2009). Penang consists of two geographically different entities: a 29,300 ha island called Penang Island ("Pulau Pinang" in Malay Language) and a portion of the mainland called Seberang Prai with an area of 73,800 ha (Almayahi et al., 2012).

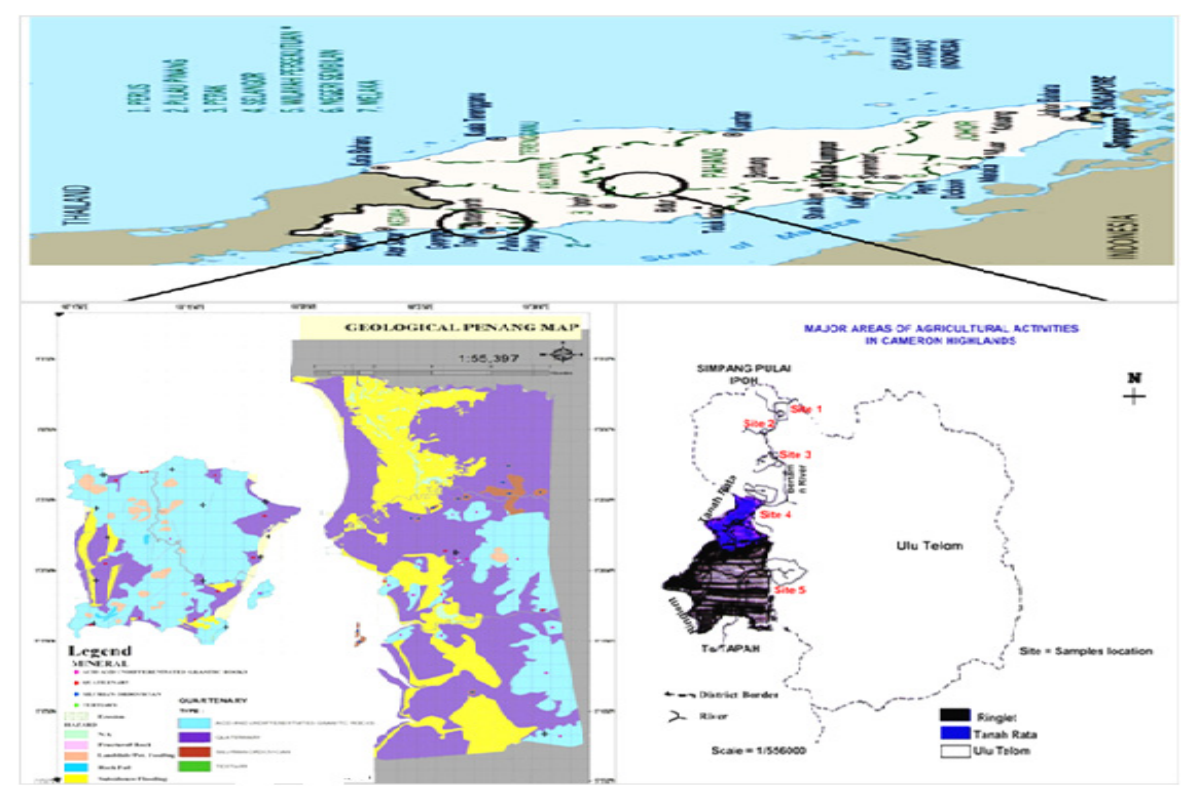

Figure 1. Map of Cameron Highlands and Penang shows the area of the present study

\subsection{Sample Preparation}

Soil samples were crushed, sieved, dried in oven at $110^{\circ} \mathrm{C}$ for about $24 \mathrm{~h}$ until the weight of the samples became constant. In case of vegetable samples, only those that were suitable for eating purposes were collected. The vegetable samples were washed several times in order to remove dust and surface contamination. These samples were dried in an oven at $110^{\circ} \mathrm{C}$ for $24 \mathrm{~h}$ and placed in a furnace. The furnace temperature was initially set at $200{ }^{\circ} \mathrm{C}$ until reaching $350{ }^{\circ} \mathrm{C}$. The samples were allowed to ash at this temperature for $24 \mathrm{~h}$. The ash samples were cooled to room temperature. The cooled ash samples were weighed (IAEA, 1989; Chibowski et al., 1999). Twenty samples of soil and vegetables were prepared and sent to Malaysian Nuclear Agency for irradiation using 
a reactor. Each sample about $0.2 \mathrm{~g}$ was prepared in a polyethylene vial and labelled, as shown in Figure 2 . Each sample has duplicated to assure quality of the analytical technique. Table 1, showed the procedure was used to irradiated for 6-12 h. After the irradiation, the measurement is performed after a suitable cooling time to get secular equilibrium. The high purity germanium detector was used to measure the uranium and thorium at the peaks $277.5 \mathrm{kev}$ for ${ }^{239} \mathrm{~Np}$ and $311.8 \mathrm{kev}$ for ${ }^{233} \mathrm{~Pa}$, respectively.

Table 1. Nuclides formed by neutron activation analysis

\begin{tabular}{ccccc}
\hline Procedure & Elements & Nuclides & Half-life & Gamma-ray energy (Kev) \\
\hline Irradiation (6-12) hand cooling (3-5) d & ${ }^{238} \mathrm{U}$ & ${ }^{239} \mathrm{~Np}$ & $2.35 \mathrm{~d}$ & 277.5 \\
Irradiation (6-12) hand cooling (20-30) d & ${ }^{232} \mathrm{Th}$ & ${ }^{233} \mathrm{~Pa}$ & $27 \mathrm{~d}$ & 311.8 \\
\hline
\end{tabular}

\subsection{Neutron Activation Analysis}

NAA is a sensitive multi element analytical method for accurate and precise determining of elemental concentrations in unknown materials. Sensitivities are sufficient to measure certain elements at the nanogram level and below although the method is well suited for the determination of the major and minor elemental components based on the detection and measurement of the characteristic gamma rays emitted from radioactive isotopes produced in the sample upon irradiation with neutrons. Typically, unknown samples together with standard materials of known elemental concentrations are irradiated with thermal neutrons in a reactor. After some appropriate decay period, high resolution gamma ray spectroscopy is performed to measure the intensity and the energies of the gamma lines emitted. A comparison between specific activities induced in the standards and unknowns will help provide the basis for comparison of elemental abundances.

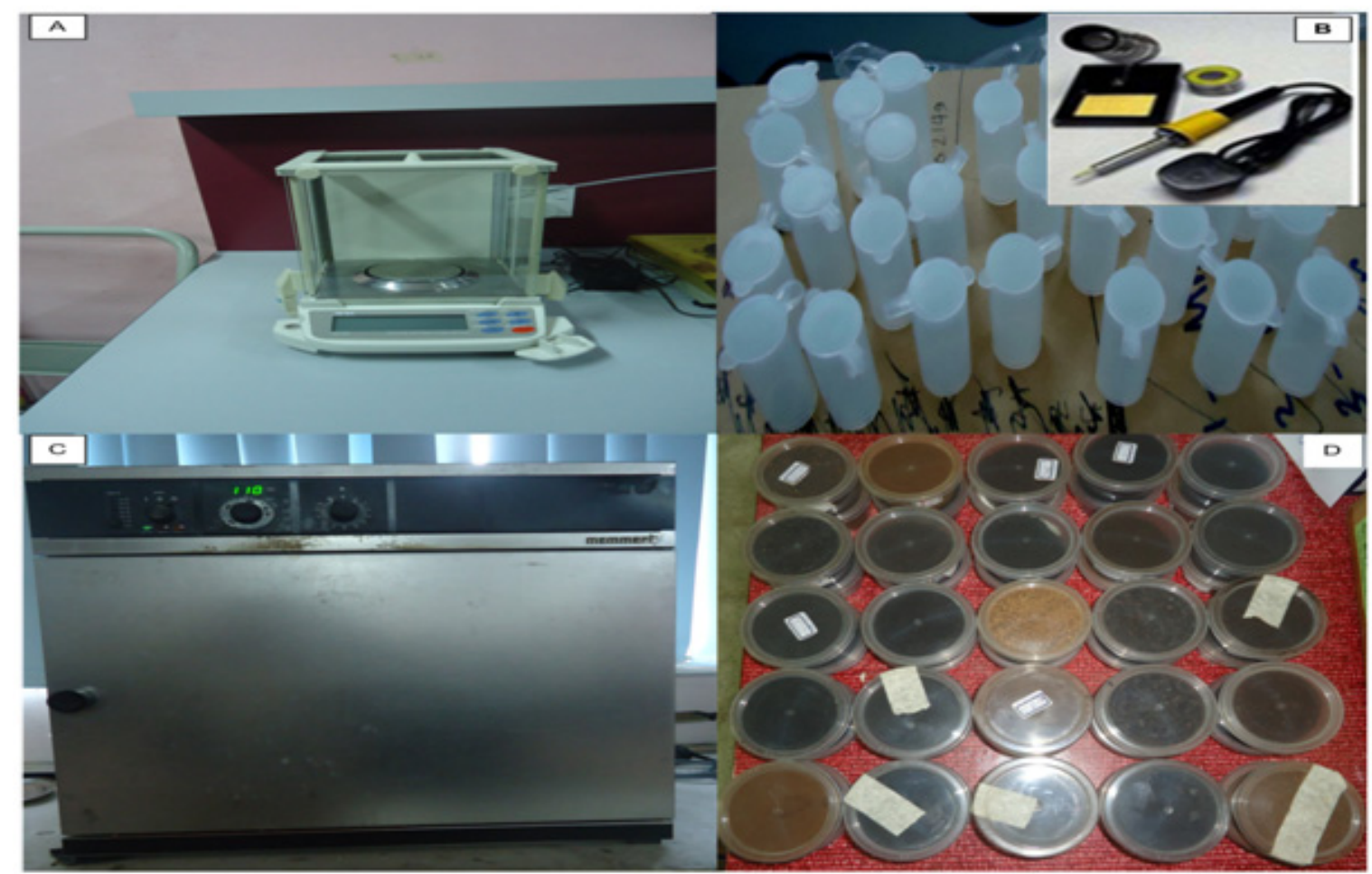

Figure 2. The materials which were used to prepare the samples; A: The balance to measure the weight; B: Vial to store the samples and the soldering iron; C: Oven at $110{ }^{\circ} \mathrm{C}$ and; D: Samples of vegetables

\subsection{Calculation of Elements Concentration}

The concentration was calculated by using a general procedure (i.e., ppm of the element) in the unknown sample 
to irradiate the latter and a comparator standard containing a known amount of the element of interest in the reactor. The Equation (1), where $\mathrm{C}$ is the concentration of the sample collected (ppm) and standard sample (ppm); Wstd is the weight of the standard sample and sample collected; $N$ is the net counts of the photopeak area for the standard sample and the samples collected. Used this equation to calculate the mass of an element in the unknown sample and that was relative to the comparator standard is

$$
\mathrm{C}_{\mathrm{samp}}=\frac{C s t d \times W s t d \times N s a m p}{W \text { samp } \times N \text { std }}
$$

\section{Results and Discussion}

The activity concentrations of natural radionuclides present in the soil sample farms in the Cameron Highlands and Penang were measured by neutron activation analysis, as illustrated in Table 2. The results for natural radionuclides are reported in $\mathrm{Bq} / \mathrm{kg}$ on a dry-weight basis. In Cameron Highlands farms, it was found that for ${ }^{238} \mathrm{U}$, the activity concentration ranged from $141 \pm 1.41 \mathrm{Kg}$ Tringkap to $295.5 \pm 1.00$ in Blue Valley, with an average of $203.83 \pm 2.05$. For ${ }^{232} \mathrm{Th}$, the activity concentration ranged from $141 \pm 1.41$ in Tringkap to $216.5 \pm$ 2.24 in Blue Valley, with an average of $186.17 \pm 335$. In Penang's farm, the activity concentration of ${ }^{238} \mathrm{U}$ ranged from $61.0 \pm 1.41$ in Juru to $170.5 \pm 3.00$ in Ara Kuda, with an average of $110.00 \pm 2.18$. For ${ }^{232} \mathrm{Th}$, the activity concentration ranged from 89.5 \pm 2.65 in Tasek Gelugor to 165.5 \pm 2.65 in Ara Kuda, with an average of 130.00 \pm 3.18 . The activity concentrations of ${ }^{238} \mathrm{U}$ and ${ }^{232} \mathrm{Th}$ in the soil were not uniform; it varied from soil to soil and from location to location, depending upon the geological characters of the area under study. Furthermore, the highlands farm was found to have a higher concentration than the land farms.

The activity concentrations of natural radionuclides present in the vegetable samples are given in Table 3 . The results were reported in $\mathrm{Bq} / \mathrm{kg}$ on dry-weight basis. In Cameron Highlands, the concentration of uranium was the highest in cucumber; it reached $6.25 \pm 1.58$ whereas in tomato, it was the lowest; it reached $1.3 \pm 0.14$. For the concentrations of thorium, it was found that in lettuce, the concentration was the highest; it reached $2.5 \pm 1.55$ whereas it was $0.41 \pm 0.12$ in tomato, eggplant, pumpkin and cucumber. In Penang, the highest concentration of uranium was in eggplant of about $3.10 \pm 1.10$, while the lowest was in chilli of about $<1.3 \pm 0.41$. As for the concentrations of thorium in okra and tomato, they were $0.41 \pm 0.12$ while in eggplant, onion and chilli, they were estimated to be $<0.41 \pm 0.12$. The absorption of radionuclides is affected by various parameters, such as the chemical and physical properties of soil and radionuclides, plant species, stage of growth, temperature, rainfall, sunlight, etc. (Carini, 2001).

The trend of ${ }^{238} \mathrm{U}$ activity in Cameron Highlands in the selected samples was found to be in the following order: Cucumber $>$ Lettuce $>$ Eggplant $>$ Pumpkin $>$ Tomato. On the other hand, the trend of ${ }^{238} \mathrm{U}$ activity in Penang in the selected samples took the following order: Eggplant $>$ Okra $>$ Onion $>$ Tomato $>$ Chilli.

As far as the transfer factors (TF) of different vegetable samples, they were also calculated in the present study. Transfer factor is a useful parameter for a radiological assessment and is defined as the steady state concentration between one physical situation and another. Equation (2) is used to determine the transfer factor between vegetables and soil (Wang et al., 1997; Chibowski et al., 1999), as illustrated below:

$$
\mathrm{TF}=\frac{C v}{C s}
$$

where TF is transfer factor of vegetables-soil; $\mathrm{C}_{\mathrm{v}}$ is the concentration of radionuclides in $\mathrm{Bq} / \mathrm{kg}$ dry vegetables weight; $\mathrm{C}_{\mathrm{s}}$ is the concentration of radionuclides in $\mathrm{Bq} / \mathrm{kg}$ dry soil weight.

The transfer factors of ${ }^{238} \mathrm{U}$ and ${ }^{232} \mathrm{Th}$ in the analyzed soil and vegetables were presented in Table 4. In Cameron Highlands, the average values of transfer factor were 0.015 and 0.004 , respectively. On the other hand, the average values of the transfer factor in Penang of both ${ }^{238} \mathrm{U}$ and ${ }^{232} \mathrm{Th}$ found in soil and vegetable samples were 0.017 and 0.003 , respectively. Figure 3 shows the transfer factor with the type of vegetables. The highest transfer factor in Cameron Highlands for uranium was in cucumber, 0.031 while the highest transfer factor for thorium was in lettuce, 0.013 . In Penang, the highest transfer factor in eggplant was 0.028 whereas the other vegetables have a similar transfer factor of thorium was 0.003 . The results showed that the highest average transfer factor was in Penang farms rather than in farms Cameron Highlands. The uptake of the isotope from soil by vegetables depends upon various interrelated soil properties, including texture, clay content, dominant clay minerals, cation exchange capacity, exchangeable cations, $\mathrm{pH}$ and organic matter contents. It also varies depending on the chemical and physical forms of the radionuclides, plant species, stage of growth, etc. (Carini, 2001). In Table 5, the results of the present work are provided for comparison with results from some other countries worldwide. By comparing our results with that of Table 5, one can find that the concentration of the studied area is higher 
than in the USA, Perak (Malaysia) and the world (UNSCEAR, 2000; Eisenbud et al., 1997; Siak et al., 2009). Furthermore, the results are lower than the ones reported in Nigeria (Jibiri et al., 2007). The values from all practical purposes are seen to pose no serious health burden to the population; a point that is consistent with the world average. In Table 6, the results of the transfer factor in the present work are provided for comparison with results from some other countries worldwide (Hasan et al., 2010; Jibiri et al., 2007; Staven et al., 2003; Al-Masri et al., 2008; Matiullah et al., 2008). The results obtained showed that the transfer factor is in line with worldwide results.

Table 2. Concentrations of ${ }^{238} \mathrm{U}$ and ${ }^{232} \mathrm{Th}$ in the soil samples in Cameron Highlands and Penang

\begin{tabular}{|c|c|c|c|c|}
\hline \multirow{2}{*}{ Location } & \multicolumn{2}{|c|}{ Coordinates } & \multicolumn{2}{|c|}{ Concentration $(\mathrm{Bq} / \mathrm{kg})$} \\
\hline & North & East & ${ }^{238} \mathrm{U}$ & ${ }^{232} \mathrm{Th}$ \\
\hline \multicolumn{5}{|l|}{ Cameron Highlands } \\
\hline Blue Valley & $04^{\circ} 35^{\prime \prime} 38.2$ & $101^{\circ} 25^{\prime \prime} 39.7$ & $295.5 \pm 1.00$ & $216.5 \pm 2.24$ \\
\hline Kg Kuala Terla & $04^{\circ} 32^{\prime \prime} 55.7$ & $101^{\circ} 25^{\prime \prime} 01.6$ & $146 \pm 3.46$ & $169.5 \pm 2.65$ \\
\hline Kg Tringkap & $04^{\circ} 30^{\prime \prime} 31.0$ & $101^{\circ} 25^{\prime \prime} 23.9$ & $141 \pm 1.41$ & $141 \pm 1.41$ \\
\hline Tamah Rata & $04^{\circ} 27^{\prime \prime} 27.8$ & $101^{\circ} 21^{\prime \prime} 56.7$ & $244 \pm 1.41$ & $212 \pm 5.66$ \\
\hline Ringlet & $04^{\circ} 26^{\prime \prime} 40.0$ & $101^{\circ} 23^{\prime \prime} 27.8$ & $206 \pm 2.00$ & $191.5 \pm 3.32$ \\
\hline Kg Bertam Valley & $04^{\circ} 24^{\prime \prime} 50.7$ & $101^{\circ} 24^{\prime \prime} 09.5$ & $190.5 \pm 3.00$ & $186.5 \pm 4.80$ \\
\hline$* *$ & & & $203.83 \pm 2.05$ & $186.17 \pm 3.35$ \\
\hline \multicolumn{5}{|l|}{ Penang } \\
\hline Ara Kuda & $05^{\circ} 26^{\prime \prime} 43.9$ & $100^{\circ} 30^{\prime \prime} 35.9$ & $170.5 \pm 3.00$ & $165.5 \pm 2.65$ \\
\hline Tasek Gelugor & $05^{\circ} 27^{\prime \prime} 45.0$ & $100^{\circ} 30^{\prime \prime} 47.2$ & $98.5 \pm 2.12$ & $89.5 \pm 2.65$ \\
\hline Juru & $05^{\circ} 17^{\prime \prime} 48.7$ & $100^{\circ} 28^{\prime \prime} 18.0$ & $61 \pm 1.41$ & $135 \pm 4.24$ \\
\hline$* *$ & & & $110.00 \pm 2.18$ & $130.00 \pm 3.18$ \\
\hline
\end{tabular}

** Mean

Table 3. Concentrations of ${ }^{238} \mathrm{U}$ and ${ }^{232} \mathrm{Th}$ in vegetables sample in Cameron Highlands and Penang

\begin{tabular}{|c|c|c|c|}
\hline \multirow[t]{2}{*}{ Name of samples } & \multirow{2}{*}{ Location } & \multicolumn{2}{|c|}{ Concentration $(\mathrm{Bq} / \mathrm{kg})$} \\
\hline & & ${ }^{238} \mathrm{U}$ & ${ }^{232} \mathrm{Th}$ \\
\hline & on Highlanc & & \\
\hline Tomato & & $1.30 \pm 0.14$ & $0.41 \pm 0.12$ \\
\hline Eggplant & & $1.90 \pm 1.09$ & $0.41 \pm 0.12$ \\
\hline Lettuce & & $4.35 \pm 1.14$ & $2.5 \pm 1.55$ \\
\hline Pumpkin & & $1.90 \pm 1.09$ & $0.41 \pm 0.12$ \\
\hline \multirow[t]{2}{*}{ Cucumber } & & $6.25 \pm 1.58$ & $0.41 \pm 0.12$ \\
\hline & & & \\
\hline Eggplant & & $3.10 \pm 1.10$ & $<0.41 \pm 0.12$ \\
\hline Onion & & $1.30 \pm 0.14$ & $<0.41 \pm 0.12$ \\
\hline Okra & & $2.50 \pm 1.26$ & $0.41 \pm 0.12$ \\
\hline Chilli & & $<1.3 \pm 0.41$ & $<0.41 \pm 0.12$ \\
\hline Tomato & & $1.30 \pm 0.41$ & $0.41 \pm 0.12$ \\
\hline
\end{tabular}


Table 4. Soil-to-vegetable transfer factors expressed as $\mathrm{Bq} / \mathrm{kg}$ fresh weight vegetable to $\mathrm{Bq} / \mathrm{kg}$ dry weight soil

\begin{tabular}{|c|c|c|c|}
\hline \multirow[t]{2}{*}{ Location } & \multirow[t]{2}{*}{ Name of samples } & \multicolumn{2}{|c|}{ Transfer Factors (TF) } \\
\hline & & ${ }^{238} \mathrm{U}$ & ${ }^{232} \mathrm{Th}$ \\
\hline \multicolumn{4}{|c|}{ Cameron Highlands } \\
\hline & Tomato & 0.006 & 0.002 \\
\hline & Eggplant & 0.009 & 0.002 \\
\hline & Lettuce & 0.021 & 0.013 \\
\hline & Pumpkin & 0.009 & 0.002 \\
\hline & Cucumber & 0.031 & 0.002 \\
\hline Mean & & 0.015 & 0.004 \\
\hline \multicolumn{4}{|l|}{ Penang } \\
\hline & Eggplant & 0.028 & 0.003 \\
\hline & Onion & 0.012 & 0.003 \\
\hline & Okra & 0.023 & 0.003 \\
\hline & Chilli & 0.012 & 0.003 \\
\hline & Tomato & 0.012 & 0.003 \\
\hline Mean & & 0.017 & 0.003 \\
\hline
\end{tabular}

Table 5. Comparing the Concentrations of ${ }^{238} \mathrm{U}$ and ${ }^{232} \mathrm{Th}$ in the soil of the earth's crust of the world with that of the present study

\begin{tabular}{llll}
\hline Location & \multicolumn{2}{l}{ Activity concentration $(\mathrm{Bq} / \mathrm{kg})$} & Reference \\
\hline USA & \multicolumn{2}{c}{${ }^{238} \mathrm{U}$ series } & ${ }^{232}$ Th series \\
Malaysia (Perak) & $112(12-426)$ & 37 & Eisenbud et al., 1997 \\
Malaysia(Penang) & $184(2-799)$ & $246(19-1377)$ & Siak et al., 2009 \\
Nigeria & $216.9(10.9-470.6)^{\mathrm{a}}$ & $165(16-667)$ & Almayahi et al., 2012 \\
World & $33(16-116)$ & $734.3(122.7-189)^{\mathrm{a}}$ & Jibiri et al., 2007 \\
Present study & $203.83(141-295.5)$ & $186(7-50)$ & UNSCEAR, 2000 \\
& $110(61-170.5)$ & $130(89.5-165.5)$ & Penang farms \\
\hline
\end{tabular}

${ }^{a}$ calculated by the authors.

Table 6. Transfer factor soil-vegetables in world and comparison with the present study results

\begin{tabular}{llll}
\hline Vegetables & $\mathrm{FT}^{238} \mathrm{U}$ & $\mathrm{FT}^{232} \mathrm{Th}$ & References \\
\hline Tomato $^{\mathrm{a}}$ & 0.064 & 0.013 & Jibiri et al., 2007 \\
Vegetables & - & 0.08 & Matiullah et al., 2008 \\
Cucumber & - & 0.09 & Hasan et al., 2010 \\
Pumpkin & - & 0.04 & Hasan et al., 2010 \\
Vegetables (Syria) & 0.008 & - & Al-Masri et al., 2008 \\
Vegetables (Worldwide ) & $0.003-0.057$ & - & Staven et al., 2003; Al-Masri et al., 2008 \\
Present study & $0.006-0.028$ & $0.013-0.002$ & \\
\hline
\end{tabular}

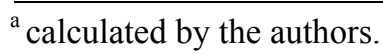



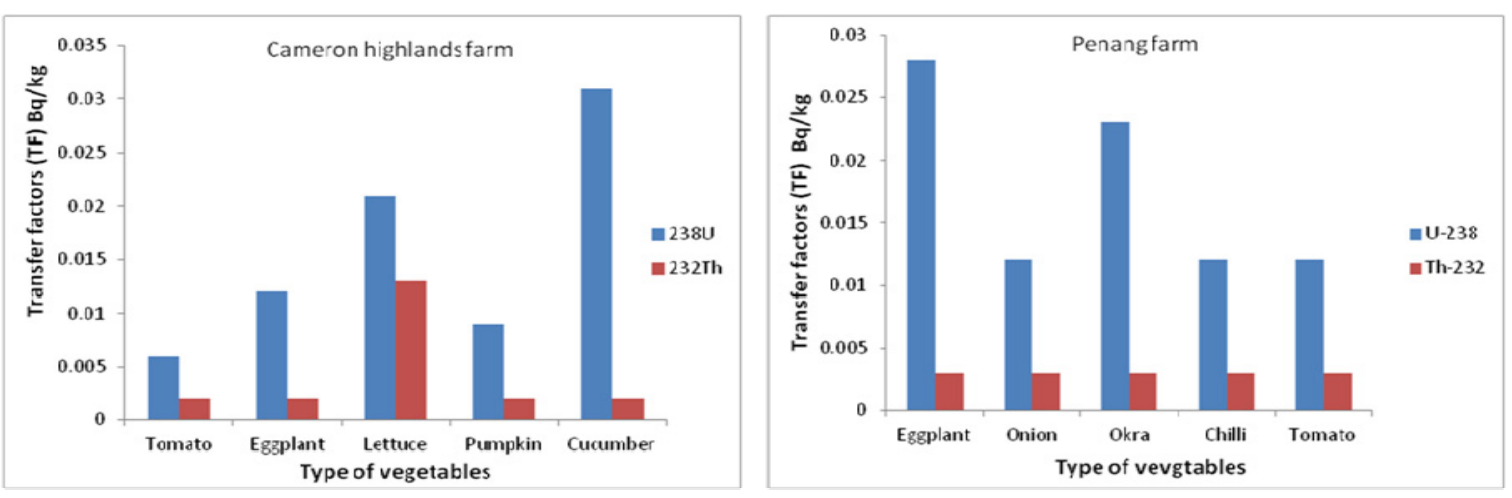

Figure 3. Shows the transfer factor with the type of vegetables in Cameron Highlands' and Penang farms

\section{Conclusions}

The activity concentrations of the ${ }^{238} \mathrm{U}$ and ${ }^{232} \mathrm{Th}$ that are present in the soil farm of Cameron Highlands and Penang were measured by a neutron activation analysis technique. In Cameron Highlands farms, the average concentration of ${ }^{238} \mathrm{U}$ and ${ }^{232} \mathrm{Th}$ was $203.83 \pm 2.05 \mathrm{~Bq} / \mathrm{kg}$ and $186.17 \pm 3.35 \mathrm{~Bq} / \mathrm{kg}$, respectively. In Penang farms, the average concentration of ${ }^{238} \mathrm{U}$ and ${ }^{232} \mathrm{Th}$ was $110.00 \pm 2.18 \mathrm{~Bq} / \mathrm{kg}$ and $130.00 \pm 3.18 \mathrm{~Bq} / \mathrm{kg}$, respectively.

The activity concentrations of ${ }^{238} \mathrm{U}$ and ${ }^{232} \mathrm{Th}$ in the soil were not uniform and varied from soil to soil and location to location, depending upon the geological characters of the area under study. The Highland farms have higher concentrations than the ground farms do. The comparison shows that the concentration is highly considerable with the world (UNSCEAR, 2000) and these values from all practical purposes are seen to pose no serious health burden to the growth of population and are in line with the world average.

The activity concentrations of ${ }^{238} \mathrm{U}$ and ${ }^{232} \mathrm{Th}$ are present in the vegetable samples. In Cameron Highlands, the highest concentration of uranium in cucumber was $6.25 \pm 1.58 \mathrm{~Bq} / \mathrm{kg}$ and the lowest, $1.30 \pm 0.14 \mathrm{~Bq} / \mathrm{kg}$, was in tomato. Furthermore, the highest concentration of thorium was in lettuce, $2.5 \pm 1.55 \mathrm{~Bq} / \mathrm{kg}$ and the lowest; 0.41 $\pm 0.12 \mathrm{~Bq} / \mathrm{kg}$ was in tomato, eggplant, pumpkin and cucumber.

In Penang, the highest concentration of uranium was in the eggplant, $3.10 \pm 1.10 \mathrm{~Bq} / \mathrm{kg}$ and the lowest in chilli, $<1.3 \pm 0.41 \mathrm{~Bq} / \mathrm{kg}$. In addition, the highest concentration of thorium was in okra and tomato, $0.41 \pm 0.12 \mathrm{~Bq} / \mathrm{kg}$ while in eggplant, onion and chilli, it was estimated to be $<0.41 \pm 0.12 \mathrm{~Bq} / \mathrm{kg}$.

The trend of ${ }^{238} \mathrm{U}$ activity in Cameron Highlands can be concluded in the following order: Cucumber $>$ Lettuce $>$ Eggplant $>$ Pumpkin $>$ Tomato. On the other hand, the trend of ${ }^{238} \mathrm{U}$ activity in Penang has the following order: Eggplant $>$ Okra $>$ Onion $>$ Tomato $>$ Chilli. The results obtained showed that the transfer factor is consistent with that of the worldwide.

\section{Acknowledgements}

The authors are grateful to Dr. Suhaimi Hamzah and Mr Lim, Nuclear Malaysia Agency for assisting us throughout conducting the present research. Financial support was provided by the School of Physics, Universiti Sains Malaysia 1001/PFIZIK 846086.

\section{References}

Al-Masri, M. S., Al-Akel, B., Nashawani, A., Amin, Y., Khalifa, K. H., \& Al-Ain, F. (2008). Transfer of ${ }^{40}$ K, ${ }^{238}$ U, ${ }^{210} \mathrm{~Pb}$, and ${ }^{210} \mathrm{Po}$ from soil to plant in various locations in south of Syria. Journal of Environmental Radioactivity, 99, 322-331. http://dx.doi.org/10.1016/j.jenvrad.2007.08.021

Almayahi, B. A., Tajuddin, A. A., \& Jaafar, M. S. (2012). Effect of the natural radioactivity concentrations and ${ }^{226} \mathrm{Ra}{ }^{238} \mathrm{U}$ disequilibrium on cancer diseases in Penang, Malaysia. Radiation Physics and Chemistry, 81, 1547-1558. http://dx.doi.org/10.1016/j.radphyschem.2012.03.018

Carini, F., \& Bengtsson, G. (2001). Post-deposition transport of radionuclides in fruit. Journal of Environmental Radioactivity, 52, 215-236. http://dx.doi.org/10.1016/S0265-931X(00)00034-5 
Chibowski, S., \& Gładysz, A. (1999). Examination of radioactive contamination in the soil-plant system and their transfer to selected animal tissues. Polish Journal of Environmental Studies, 8(1), 19-23.

Eisenbud, M., \& Gesell, T. (1997). Environmental radioactivity from natural, industrial, and military sources (4th ed.). San Diego, USA: Academic Press.

Hasan, M. K., Zahid, S. C., Muhammad, I., \& Khalid, K. (2010). Assessment of radionuclides, trace metals and radionuclide transfer from soil to food of jhangar valley (pakistan) using gamma-ray spectrometry. Water Air Soil Pollute, 213, 353-362. http://dx.doi.org/10.1007/s11270-010-0390-4

IAEA. (1982). International atomic energy agency. generic models and parameters for assessing the environmental transfer of radionuclides from routine releases. Exposure of Critical Groups. Safety Series (No. 57), Vienna.

IAEA. (1989). Measurement of radionuclides in food and the environment. Tech. Rep. Series (No. 295), Vienna.

Jibiri, N. N., Farai, I. P., \& Alausa, S. K. (2007). Estimation of annual effective dose due to natural radioactive elements in ingestion of foodstuffs in tin mining area of Jos-Plateau. Nigeria Journal of Environmental Radioactivity, 94, 31-40. http://dx.doi.org/10.1016/j.jenvrad.2006.12.011

Khan, H. M., Khan, K., Atta, A. A., \& Jan, F. (1995). Determination of naturally occurring potassium-40 in some meat, milk and egg samples. Journal of Nuclear Science, 32, 249.

Kumaran, S., \& Ainuddin, A. N. (2004). Forests, water and climate of cameron highlands, faculty of forestry, Universiti Putra Malaysia.

Mahdieh, E., \& Amirhossein, M. (2009). Water quality assessment of bertam river and its tributaries in cameron highlands, malaysia. World Applied Sciences Journal, 7, 769-776.

Matiullah, M., Ahad, A., Munazz, Faheem., Tabassum, N., \& Said, R. (2008). Measurement of radioactivity in vegetation of the Bahawalpur Division and Islamabad federal capital territory-Pakistan. Radiation Measurements, 43, S532-S536. http://dx.doi.org/10.1016/j.radmeas.2008.04.042

Muhammad, B. G., Ismail, S., Ekhwan, T., Joy, J. P., Mazlin, M., \& Pauzi, A. M. (2009). Integrated Water Resource Management and Pollution Sources in Cameron Highlands, Pahang, Malaysia. American-Eurasian Journal Agriculture \& Environmental Science, 5, 725-732.

Pulhani, V. A., Dafauti, S., Hegde, A. G., Sharma, R. M., \& Mishra, U. C. (2005). Uptake and distribution of natural radioactivity in wheat plants from soil. Journal of Environmental Radioactivity, 79, 331-346. http://dx.doi.org/10.1016/j.jenvrad.2004.08.007

Siak, K. L., Husin, W. A., Ramli, A. T., Nursama, H. A., \& Khalik,W. A. (2009). Radiological monitoring: terrestrial natural radionuclides in Kinta District, Perak, Malaysia. J. Environ. Radioact., 100, 368-374. http://dx.doi.org/10.1016/j.jenvrad.2009.01.001

Staven, L. H., Rhoads, K., Napier, B. A., \& Strenge, D. L. (2003). A Compendium of Transfer Factors for Agricultural and Animal Products. Pacific Northwest National Laboratory, Richland, Washington, USA. http://dx.doi.org/10.2172/15010186

UNSCEAR. (2000). Sources and Effects of Ionizing Radiation. United Nations Scientific Committee on the Effects of Atomic Radiation, Report to the General Assembly with Scientific Annexes. United Nations: New York.

Wang, C. J., Lai, S. Y., Wang, J. J., \& Lin, Y. M. (1997). Transfer of radionuclides from soil to grass in northern Taiwan. Applied Radiation and Isotopes, 48, 301-303. http://dx.doi.org/10.1016/S0969-8043(96)00178-9

WWF Malaysia. (2001). Study for the sustainable development of the highlands of peninsular Malaysia. Economic Planning Unit, Prime Minister's Department.

\section{Copyrights}

Copyright for this article is retained by the author(s), with first publication rights granted to the journal.

This is an open-access article distributed under the terms and conditions of the Creative Commons Attribution license (http://creativecommons.org/licenses/by/3.0/). 